\title{
INFECIIOUS DISEASES
}

Research Article: Chlamydia trachomatis IgM and gG antibodies and associated risk factors of among positive and negative HIV women attending consultation at the Mbouo-Banjoun Presbyterian Hospital West Region of Cameroon

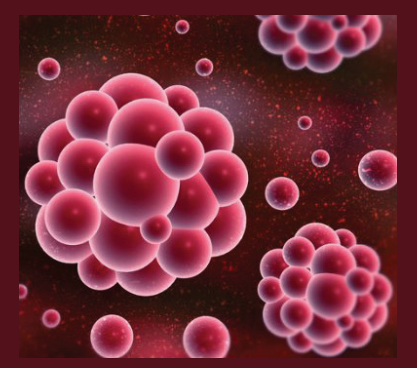

Issue Type: Volume1 Issue2

Author Name:

Leonard Fonkeng Sama ${ }^{1 *}$, Michel Noubom $^{2}$, Romeo Joël Nguekam ${ }^{1}$, Solange Dabou ${ }^{3}$, Thibau Flaurant Tchouangueu $^{1}$ and Christopher Bonglavnyuy Tume ${ }^{1,5}$

1 Unit of Microbiology and Antimicrobial Substances, Department of Biochemistry, University of Dschang 2 Faculty of Medical and pharmaceutical Sciences, Department of Microbiology and Immunology, University of Dschang, Cameroon, University of Dschang

3 Laboratory of Biochemistry, Medicinal Plants, Food Security and Nutritional Sciences (LABPMAN), University of Dschang, Dschang, Cameroon, P.O. Box 67, Dschang, Cameroon

5 University of Bamenda, Faculty of Science, Department of Biochemistry, University of Bamenda, Cameroon

\section{Corresponding Author:}

Leonard Fonkeng Sama

Citation: Leonard Fonkeng Sama Chlamydia Trachomatis IgM and $\mathrm{gG}$ antibodies and associated risk factors of among positive and negative HIV women attending consultation at the Mbouo-Banjoun Presbyterian Hospital West Region of Cameroon

\section{Received Date: 5th March 2020}

Published Date: 25th March 2021

Copyrights: Leonard Fonkeng Sama This is an open access article distributed under the Creative Commons Attribution License, which permits unrestricted use, distribution, and reproduction in any medium, provided the original work is properly cited.

\begin{abstract}
Background

Chlamydia trachomatis (CT) infection in the genitourinary tract is the most prevalent bacterial sexually transmitted disease (STD) worldwide. Genital chlamydial infection has a huge impact on sexual and reproductive health, and it is very common in developed and developing countries. This study aimed to determine the seroprevalance and risk factors for C. trachomatisinfection in women seeking medical care in the locality of Mbouo-BanjounWest Region of Cameroon.
\end{abstract}

Methods: We conducted a cross-sectional hospital based study from November 2016 to June 2017 in which we recruited 204 consenting women aged 18 to 55 years.A questionnaire was administered to study participants and potential risk factors for Chlamydia exposure sought. Venous blood was collected and serum from each participant analysed for $C$. trachomatis infection as evidenced by positive anti- $C$. trachomatisIgG and IgM antibodies detected using the Sandwich Enzyme-Linked ImmunoSorbent Assay (ELISA) technique. The proportion of anti-C. trachomatis antibody was calculated and predictors of $C$. trachomatis infection analysed by univariate and multivariate regression. Epi-Info 7 was used for statistical analyses. A $\mathrm{p}<0.05$ was considered significant in all analyses.

Results: The seroprevalence of anti-C. trachomatisantibodies (IgM or IgG) was found to be62.25\% [127/204]. Among seropositive women, 37.15\% [77/204] were seropositive for IgG antibodies while 47.54\% [97/204] were seropositive for IgM antibodies and 23.04\% [47/204] where seropositive for both IgM and IgG antibodies. Among the risk factors evaluated, marital status $(\mathrm{P}=0.03)$ and knowledge of Chlamydia $(\mathrm{P}=0.001)$ were observed to be an independent risk factor of C. trachomatisinfection.

Conclusions: Our findings suggest recent $C$. trachomatisexposure is high in our study population, and may constitute a significant risk factor for, ocular and pulmonary infection in new born child, infertility to women. Education and screening of HIV-positive individuals and pregnant women for C. trachomatisinfection may be important primary prevention strategies in this population.

Keywords: Chlamydia, Seroprevalence, IgG, IgM, Antibodies, women, Cameroon

\section{Introduction:}

Chlamydia trachomatis (CT) infection in the genitourinary tract is the most prevalent bacterial sexually transmitted disease (STD) worldwide [1]. Genital chlamydial infection has a huge impact on sexual and reproductive health, and it is very common in developed and developing countries [2-4]. Chlamydia is also known as the silent STI due to its lack of symptoms in infected individuals particularly females. Chlamydia infection can lead to serious sequelae such as pelvic inflammatory diseases (PID), tubal factor infertility, ectopic pregnancy and chronic pelvis pain in women [5]. In men Chlamydia leads to non-gonococcal urethritis (NGU), epididymitis andproctitis among others [5]. Understanding the epidemiology of chlamydia is therefore the first step towards its control. According to theWHO estimates, globally 92 million new cases of $C$. trachomatis infection occur each year and about twothirds of these cases occur in the developing world, where diagnostic and treatment services are scarce [6].Most epidemiological data on Chlamydia trachomatis 
infection (CTI) are from industrialised nations and reliable data from the developing nation'sarea where the disease burden is concentrated are rare. However, it is important to document laboratory-confirmed incidence and prevalence of CTI from the developing world as well.The available African data obtain from the studies conducted in Kenya, Zimbabwe, Nigeria and South Africa, have shown a wide variation in CT prevalence with infection rates ranging from $6 \%$ to $56 \%$ depending on the population sampled[7-10].Few data are available regarding CTI epidemiologyin Cameroon. Furthermore, chlamydial infection have being shown to be associated with 3-6-fold increase in the transmission of HIV infection and are attributed to be a risk factor for the development of cervical carcinoma. Also, infected patients, unaware of their infection, may serve as a reservoir of infection to their partners $[11,12]$. The control of these infections represents a unique opportunity to improve reproductive health of women living with HIV [13]. HIV-infected individuals affected by an STI have increased viral load in genital secretions, [14, 15] thereby increasing considerably their potential of infectiousness and transmission. The aim of the current study was to determine the prevalence and risk factors associated with CT among HIVinfected and HIV non-infectedwomen attending consultation at the Mbouo-BanjounPresbyterian Hospital.

\section{Material and methods \\ Study design}

A cross-sectional study was carried out from November 2016 to June 2017in Mbouo-Banjoun Presbyterian Hospital, West Region of Cameroon.

\section{Study site and population}

The Mbouo-Banjoun Presbyterian Hospital, is a private health care institution run by the Sisters of the Presbyterian Congregation whose convent is located near the hospital. The hospital was created in 1928. This hospital has an HIV treatment centre, and majority of services rendered are in the domains of gynaecology, general and orthopaedics surgery. The hospital is situated at about 2 miles away from Bafoussam the regional capital of the West Region of Cameroon. About $75 \%$ of the women in this locality depend on agriculture and trading for their livelihoods. Participants in this study were volunteer sexually active women (HIV-infected or uninfected) attending antenatal or medical check-ups at the hospital and who duly provided consent by signing or placing their thumbprint on the consent form and those who were diagnosed as being infected received standard treatment in accordance with the Sexually Transmitted Diseases Control Guidelines of the Ministry of Health.

\section{Questionnaire administration and sample collection}

After agreeing to participate, the women were interviewed by the research team. Each participant to this study was provided with a structured questionnaire. Those who could not read were assisted by the laboratory technician or antenatal care nurse. The questionnaires contained simple closed ended questions regarding socio-demographic characteristics (age, schooling, marital status, and social activity), sexual characteristics (protected or no, number of partner).

Five millilitres of venous blood were collected into two tubes pre-labelled with an anonymised patient codes. The blood from the EDTA containing tubes was immediately tested for the presence of HIV antibodies using Determine ${ }^{\circledR}$ (Alere Determine $\left.^{\mathrm{TM}} H I V-1 / 2\right)$ test strips according to manufacturer's instructions. The second blood sample was allowed to clot completely before centrifugation at $3000 \mathrm{rpm}$ for $15 \mathrm{~min}$ at $4{ }^{\circ} \mathrm{C}$ to obtain serum. Aliquotedserum samples were then stored at $-25^{\circ} \mathrm{C}$. These frozen sera were later tested for the presence of Chlamydia trachomatis (CT) antibodies.

\section{Serological test for Chlamydia trachomatis antibodies}

The presence of Chlamydia trachomatis antibodies in the participants' sera was determined using an indirect EnzymeLinked Immunosorbent Assay (ELISA). This was done using the NovaLisa Chlamydia trachomatis IgM and IgG ELISA Kits CHLG0070 (NovaTecImmunodiagnostica, GmbH, Dietzenbach, Germany). The Chlamydia trachomatis IgM and IgG ELISA Kits had a specificity of $100 \%$ and a sensitivity of $100 \%$. Calibrator and controls were run with each test assay. The procedure outlined in the kit's brochure was strictly adhered to. The micro titre wells were pre-coated with $C$. trachomatis antigen. About $10 \mu 1$ of participant's serum diluted at 1:100 with $\mathrm{IgM}$ and $\mathrm{IgG}$ sample diluent was added to each well, incubated for one hour at $37^{\circ} \mathrm{C}$ and later washed with a washing solution. After the addition of conjugate, further incubation for 30 minutes was done at room temperature. At the end of incubation, plates were again washed, TMB substrate was added and incubated for 15 mins at room temperature in the dark. Finally, stop solution was added to all the wells and Optical Density (OD) readings were taken with the wavelength of $450 \mathrm{~nm}$ using iMarkMicroplate Reader, Bio-Rad, Germany.

\section{Cut-off value calculation:}

- Cut-off value was considered as the mean absorbance value of cut-off controls kept in duplicate wells.

- Samples were considered positive if O.D readings were $10 \%$ higher than the cut-off values and those with $10 \%$ less than cutoff negative. Those in the middle Grey zone were repeated.

Calculation in Nova Tec Units Antibody index $=($ Sample O.D/ Cut-off O.D) x 10.

The samples with O.D values above 11 NTU (NovaTec units) were considered as positive and those below 9 NTU were taken as negative. Borderline samples with 9-11 NTU were repeated in triplicate.

\section{Data management and statistical analysis}

Data were entered into Microsoft Excel program and then transferred to Epi Info 7 statistical program. The Chlamydia trachomatis prevalence was calculated as the proportion of serologically positive anti-C.trachomatis samples among all samples tested at $95 \%$ confidence interval (CI). A multivariate logistic regression model was used to investigate the association between the potential risk factors for C.trachomatis as defined by seropositivity for C.trachomatis antibodies of any kind. Variables used in the multiple regression were selected through step-wise backward elimination using a $20 \%$ cut-of. The strength of associations was measured using the odds ratio (OR) at $95 \% \mathrm{CI}$. The Chi-square test was used for group comparisons. Statistical significance was set at $5 \%$ and all the associations that showed a $\mathrm{p}<0.05$ were considered significant.

\section{Results}

A total of 357 eligible women that were approached, 204 women aged 18 to 55 years provided consent for this study. The mean age of participating women was $30 \pm 8.12$ years. For the women that provide consent to participate to the study, $46.08 \%$ were aged between 26 and 35 [94/204], 32.84\% [67/204] between 18 to 25 and $21.08 \%$ [43/204] above 36 years. A total of $45.59 \%$ 
(93/204) of the women were single, 14.22\% [29/204], 64.71\% [132/204] and 21.08\% [43/204] had primary, secondary and higher level of education whereas 59.31\% [121/204] has no Knowledge of Chlamydiaon infection.

Amongst all the participants, 32.84\% [67/204] had more than one sex partner, $26.96 \%$ [55/204] has protected and unprotected sexual intercourse, $67.16 \%$ [137/204] are using public toilet and 44.12\% [90/204] where HIV positive (table 1).

\section{Prevalence of anti-C.Trachomatis antibodies}

The overall seroprevalance of anti-C.trachomatis antibodies among the 204 women in this study was 62.25\% [127/204]. Among this seropositive women, 37.15\% [77/204] were seropositive for IgG antibodies while 47.54\% [97/204] were seropositive for $\operatorname{IgM}$ antibodies and 23.04\% [47/204] where seropositive for both $\operatorname{IgM}$ and $\mathrm{IgG}$ antibodies. From the overall seropositive patients to anti-C.trachomatis antibodies,significant difference $(\mathrm{P}=0.001)$ were observe between HIV positive and HIV negative with $63.33 \%$ [57/90] HIV positive women been positive foranti-C.trachomatis antibodies and 67.31\% [70/104] HIV-negative women been positive foranti-C.trachomatis antibodies. Significant difference $(\mathrm{P}=0.0000)$ was observe between HIV-positive and HIV-negative women seropositive for C.trachomatisIgG antibodies with 36.67\% [33/90] HIVpositive women been seropositive for C.trachomatisIgG antibodies and 42.31\% [44/104] HIV-negative women been positive for IgG antibodies. However, between HIV-positive and HIV-negativesignificant different $(\mathrm{P}=0.0025)$ was observe for C.trachomatisIgM antibodies with 55.56\% [50/90] of HIVpositive women been positive for C.trachomatisIgM antibodies and $45.19 \%$ [47/104] been positive for C.trachomatisIgM antibodies. Significance difference $(\mathrm{P}=0.0070)$ was also observe between HIV positive been positive to both C.trachomatisIgM and IgG antibodies with $28.89 \%$ [26/90] HIV-positive women been positive to both C.trachomatisIgM and IgG antibodies and $20.19 \%$ [21/104] HIV-negative been positive to both C.trachomatisIgM and IgG antibodies (table 2).

Table 3 shows the prevalence of $C$. trachomatis in relation to socio-demographic characteristic. From this table, we observe according to age category, HIV status, IgM and $\operatorname{IgG}$ antibodiesthat, the highest prevalence of $30.00 \%$ IgMoccurred for patient age between $25-35$ years $(\mathrm{X} 2=0.9195 ; \mathrm{P}=0.6314)$ whereas for $\mathrm{IgG}$, the highest of $27.19 \%$ occurred for HIV negative age between $18-25$ years $26-35$ years $(\mathrm{X} 2=3.3465 ; 2$ $\mathrm{P}=0.1794)$. The highest prevalence of $44.44 \% \operatorname{IgM}$ occurred for single HIV positive women (X2 $=3.0606 ; \mathrm{P}=0.3824)$ whereas for IgG, the higher prevalence's of $38.60 \%$ single occurred for HIV negative (X2 =6.0913; $\mathrm{P}=0.1073$ ).

According to the Knowledge on Chlamydia, the higher prevalence of $34.44 \%$ IgM occurred for HIV positive women whom have no knowledge on Chlamydia infection $(\mathrm{X} 2=$ $7.5824 ; \mathrm{P}=0.0058)$ whereas the higher prevalence of $21.05 \%$ IgG occurred for HIV negative whom known about Chlamydia infection $(\mathrm{X} 2=4.3380 ; \mathrm{P}=0.0037)$. The higher prevalence of $41.23 \%$ IgM occurred for HIV negative women using common toilet and higher prevalence of $38.60 \%$ IgG occurred in HIV negative women using common toilet $(\mathrm{X} 2=1.5830, \mathrm{P}=0.4532)$. The higher prevalence of $43.33 \%$ IgM occurred for HIV negative women having more than one sexual partner $(\mathrm{X} 2=0.3862 ; \mathrm{P}=$ 0.5343 ) whereas the higher prevalence of $38.60 \%$ IgG also occurred among HIV negative patient but having one sexual partner $(\mathrm{X} 2=0.0808 ; \mathrm{P}=0.7762)$.

Looking for the Type of sexual intercourse, the higher prevalence of $33.33 \%$ IgM occurred for HIV positive women having mixed sexual intercourse (protected and non-protected) $(\mathrm{X} 2=$ $1.9229 ; \mathrm{P}=0.3823$ ) whereas for $\mathrm{IgG}$, the higher prevalence of $20.00 \%$ occurred for HIV positive women also having mixed sexual intercourse $(\mathrm{X} 2=0.1905 ; 0.6625)$. According to social activity, the higher prevalence of $27.19 \%$ IgM occurred among HIV negative student $(\mathrm{X} 2=8.1787 ; \mathrm{P}=0.0425)$, also the higher prevalence of $27.19 \%$ IgG occurred among HIV negative student $(\mathrm{X} 2=8.8541 ; \mathrm{P}=0.0313)$.

\section{Risk factors for C.trachomatisseropositivitiy}

A simple logistic regression analysis (table 4) with suspected variables indicated that no suspected risk factor was significantly associated with C.trachomatisIgGseropositivitiyantibodies type whereas Marital status $(\mathrm{P}=0.03)$, Knowledge of Chlamydia $(\mathrm{P}=0.001)$ and HIV status $(\mathrm{P}=0.04)$ were predictors of $C$. trachomatis seropositivityIgM antibody type. However, results of multiple logistic regression analysis of selected variables as shown in Table 5 showed that only the Knowledge of Chlamydia was an independent predictor ofIgM $(\mathrm{P}=0.001)$ and $\operatorname{IgG}(\mathrm{P}=$ 0.04) C. trachomatis seropositivity whereas Marital status $(\mathrm{P}=0.03)$ was independent predictor for IgM $C$. trachomatis seropositivityantobodies. No significant association was found between $C$. trachomatis seropositivityand HIV status $[\operatorname{IgM}(\mathrm{P}=$ $0.2), \operatorname{IgG}(\mathrm{P}=0.8)]$.

\section{Discussion}

It has been prove that Chlamydia is an accelerator of HIV transmission and acquisition [16]. In most women and about half of men chlamydia do not experience symptoms [17]. Since symptoms may not be present, the only way to know if a person who may be at risk, is infected with chlamydia is to be tested. In the present study, we sought to investigate Chlamydia infection, as evidenced by anti-Chlamydia antibodies in the serum of HIV positive and HIV negative women in a rural locality in Cameroon. The overall prevalence of $62.25 \%$ of anti-C.Trachomatis found in this study is higher compared to those described in those found among sex workers or among prostitutes in Cameroon [18-19] but also higher than prevalence of chlamydia in Cameroonian University Context: case of the University of Dschang, Western Region of Cameroon where the prevalence of $2 \%$ was obtain [20], to $32.1 \%$ obtained among HIV positive and HIV negative patientsin the Vhembe District of South Africa [21] and to the $1.8 \%$ prevalence obtain in São Paulo, Brasilia in the study on Prevalence and factors associated with Chlamydia trachomatis infection among women with HIV in São Paulo [22]. This high prevalence could be attributed to chlamydia being asymptomatic in most cases particularly in females whom constitute our study population. The prevalence of $\mathrm{C}$. trachomatis was significantly different $(\mathrm{P}=0.001)$ between HIV positive $(63.33 \%)$ and HIV negative (67.31\%).Similar results were obtained in a study carry in the Mopani District South Africa on prevalence of chlamydia and gonorrhoea among HIV infected women in rural Mopani District [23], but also in the study carry in Vhembe District of South Africa[21]where the prevalence of C.trachomatis was found to be high among HIV-negative compare to HIV-positive. This could mean that the prevalence of chlamydia is not always associated with the reported HIVstatus. The use of ARV also appeared toreduce the risks and sequelae of chlamydia infection [21].

The presence of IgG antibodies to trachomatis in the sera of the HIV positive and HIV-negative women as observed in this may be indicative of past chlamydia infection. The detection rate in 
HIV positive women (36.67\%) is lower than $54.2 \%$ in India [24,25], and the $42.31 \%$ detection rate in HIV negative women washigher than 15 - 40\% reported in Nigeria[26].

The lower prevalence $(36.67 \%)$ of Chlamydia trachomatis IgG antibodies among HIV positive women is significantly lower $(\mathrm{P}=0.000)$ than that of the HIV negative women $(42.31 \%)$. Which suggests that it is unlikely that previous exposure to HIV induce a higher prevalence of Chlamydia trachomatis infection, but rather Chlamydia trachomatis infection facilitate the transmission of HIV which is in support with [27,28,29] who reported that Chlamydia trachomatis infection increases the risk of HIV transmission and acquisition.

The presence of $\operatorname{IgM}$ antibodies to trachomatis in the sera of the HIV-positive and HIV-negative women as observed in this may be indicative of new chlamydia infection. The detection rate in HIV positive women $(55.56 \%)$ is higher than $3 \%$ obtain by Padmavathy Kesavaram et al. [30] and the $45.19 \%$ detection rate in HIV negative women washigher than $1.5 \%$ reported among pregnant women in Makkah [31]. The higher prevalence $(55.56 \%)$ of Chlamydia trachomatis IgM antibodies among HIV positive women is significantly higher $(\mathrm{P}=0.0025)$ than that of the HIV negative women $(45.19 \%)$. Which suggests that it is likely that previous exposure to HIV induce a higher prevalence of Chlamydia trachomatis infection.

In the present study, the prevalence was found to be high among people aged between 25-35 years (35.29 \%).Similar results have been reported by previous studies in the African continent. For example, a study carried in Vhembe District of South Africa found a prevalence of $35.6 \%$ reported in people of between 26-45 years in a study on the prevalence of chlamydia among HIV positive and HIV negative patients in the Vhembe District as detected by real time PCR from urine samples [21]. A previous study carry in South Eastern Nigeria found a high prevalence of $43.9 \%$ was reported in people of between $26-$ 30 years in a study on the prevalence of chlamydia in patients attending gynaecological clinics in South Eastern Nigeria [32]. A high prevalence of $52.8 \%$ was also reported in female miners particularly those who were aged between 46-50 years old [33]. In general no significant difference was observe between socio-demographical characteristics and the prevalence of C.trachomatis except with level of education where significant different was observe regard to IgGantibody (X2 =8.6474, $\mathrm{P}=0.0133$ ) with high prevalence found among patient of secondary level of education. Similar results have been reported in New Caledonia [34], in Vhembe District of South Africa[21] although the difference was not significantwith other educational levels. Significant difference was also reported with knowledge of Chlamydia with both $\operatorname{IgM}(\mathrm{X} 2=7.5824, \mathrm{P}=0.0058)$ and $\operatorname{IgG}(\mathrm{X} 2=4.3380, \mathrm{P}=0.0037)$ antibodies. Similar results have been reported in Scotland, UK in the study of Knowledge of Chlamydia trachomatis among men and women approached to participate in community-based screening, Scotland, UK. Significant difference was reported intype of toilet regard toIgM antibody (X2 $=6.4594, \mathrm{P}=0.0396)$ with high prevalence among patients using common toilet. Which suggests that it is unlikely that chlamydia could not be catch from toilet seats.

Socio-economic status of study participants has often been cited as risk factor for the occurrence of several diseases.In our study, we found that the prevalence of C.trachomatis was higher amongstudent compare to house wife and civil servant with significant difference. This correlates with a study that was conducted in Vhembe District of South Africa[21]. Similar results have been reported by previous studies in the United States by Klovstad et al. [27], where the percentage in people who were unemployed was higher compared to those who were employed also the differencewas not significant.

The marital status and Knowledge of Chlamydia where significantly a risk factor associated with C.trachomatis in the univariate and multivariate analysis analyses (tables 4 and 5). In addition, HIV status was observed to be significantly associated with C.trachomatis in the univariate analysis, although it was not significant in the multivariable analysis Table 4.Similar results have been observed in a review article publish by Kucinskiene et al. [41] showed a significant association between C.trachomatis infection and Knowledge of Chlamydia.

Our study however should be interpreted with some caution. Our sample size was small and conclusions from the present study must be measured. It is likely that we may obtain different results with increased sample size.

\section{Conclusions}

C.trachomatis infection appears to be a public health concern in Mbouo-Banjounwith a global antibody sero-prevalence of 62.25\%among HIV infected and HIV non-infected women attending consultation in our study area. In this study, recent infections were found in $47.54 \%$ of the study population while up to $37.15 \%$ of patients were reactivating and significant difference $(\mathrm{P}=0.001)$ was observe between HIV positive and HIV negative. Marital status, Knowledge of Chlamydia and HIV status were observedto be risk factors for C.trachomatis infection among HIV-positive and HIV-negative women attending consultation at the Mbouo-Bandjoun Presbyterian Hospital West Region, Cameroon

\section{Data Availability}

Data used to support the findings of this study are included within the article.

\section{Competing interests}

The authors declare that they have no competing interests.

\section{Ethical consideration}

Ethical clearance for this study was obtained from the Ethics Review and Consultancy Committee of the Cameroon Bioethics Initiative (CAMBIN) under the reference number $\mathrm{CBI} / 370$ / ERCC/CAMBIN of August 18th, 2015.

\section{Authors' contributions}

LFS, MN and CBT conceived the study. RJN, LFS and TFT carried out sample and data collection. EJN, LFS and SD participated in analysis of the samples, data management and statistics. SD and LFSdrafted the manuscript. All authors reviewed the manuscript the final version prior to submission. All authors read and approved the final manuscript.

\section{Acknowledgements}

We wish to thank all the participants who sacrificed their time and donated their blood for this study. We also thank particularly the Matron, Doctors, and Nurses of Mbouo-Banjoun Presbyterian Hospital for their contributions and assistance during sample collection and analysis. 
Table 1: General characteristics of study participants

\begin{tabular}{|c|c|}
\hline Characteristic & Number (\%) \\
\hline $\begin{array}{c}\text { Age category } \\
18-25\end{array}$ & $67(32.84 \%)$ \\
\hline $26-35$ & $94(46.08 \%)$ \\
\hline$>36$ & $43(21.08 \%)$ \\
\hline $\begin{array}{l}\text { Marital status } \\
\text { Married }\end{array}$ & $88(43.14 \%)$ \\
\hline Divorced & $14(6.86 \%)$ \\
\hline Single & $93(45.59 \%)$ \\
\hline Widow & $0(0,00 \%)$ \\
\hline Cohabiting & $9(4.41 \%)$ \\
\hline $\begin{array}{c}\text { Level of education } \\
\text { None }\end{array}$ & $0(0.00 \%)$ \\
\hline Primary & $29(14.22 \%)$ \\
\hline Secondary & $132(64.71 \%)$ \\
\hline Higher & $43(21.08 \%)$ \\
\hline $\begin{array}{c}\text { Knowledge of Chlamydia } \\
\text { Yes }\end{array}$ & $83(40.69 \%)$ \\
\hline $\mathrm{No}$ & $121(59.31 \%)$ \\
\hline $\begin{array}{c}\text { Type of toilet } \\
\text { Personal }\end{array}$ & $55(26.96 \%)$ \\
\hline Public & $137(67.16 \%)$ \\
\hline Commune & $12(5.88 \%)$ \\
\hline $\begin{array}{c}\text { Number of sexual partner } \\
1\end{array}$ & $137(67.16 \%)$ \\
\hline More than 1 & $67(32.84 \%)$ \\
\hline $\begin{array}{c}\text { Type of sexual intercourse } \\
\text { Protected }\end{array}$ & $42(20.59 \%)$ \\
\hline Non protected & $55(26.96 \%)$ \\
\hline mixed & $107(52.45 \%)$ \\
\hline $\begin{array}{c}\text { Social activity } \\
\text { Trader }\end{array}$ & $50(24.51 \%)$ \\
\hline Civil servant & $23(11.27 \%)$ \\
\hline House wife & $66(32.35 \%)$ \\
\hline Student & $65(31.86 \%)$ \\
\hline $\begin{array}{l}\text { HIV positive } \\
\text { Yes }\end{array}$ & $90(44.12 \%)$ \\
\hline NO & $114(55.88 \%)$ \\
\hline
\end{tabular}

Table 2 : HIV status and anti-Chlamydia trachomatisIgM and IgGas a function of sociodemographic data.

\begin{tabular}{|c|c|c|c|c|}
\hline Characteristic & HIV positive & HIV negative & Total & P-Value \\
\hline IgG+ & $33(36.67 \%)$ & $44(42.31 \%)$ & $77(37.15 \%)$ & 0.0000 \\
\hline IgM+ & $50(55.56 \%)$ & $47(45.19 \%)$ & $97(47.54 \%)$ & 0.0025 \\
\hline IgG+ and IgM+ & $26(28.89 \%)$ & $21(20.19 \%)$ & $47(23.04 \%)$ & 0.0070 \\
\hline IgG+ or IgM+ & $57(63.33 \%)$ & $70(67.31 \%)$ & $127(62.25 \%)$ & 0.6750 \\
\hline
\end{tabular}


Table 3 : Seroprevalence of antibodies to C. trachomatis according to HIV status

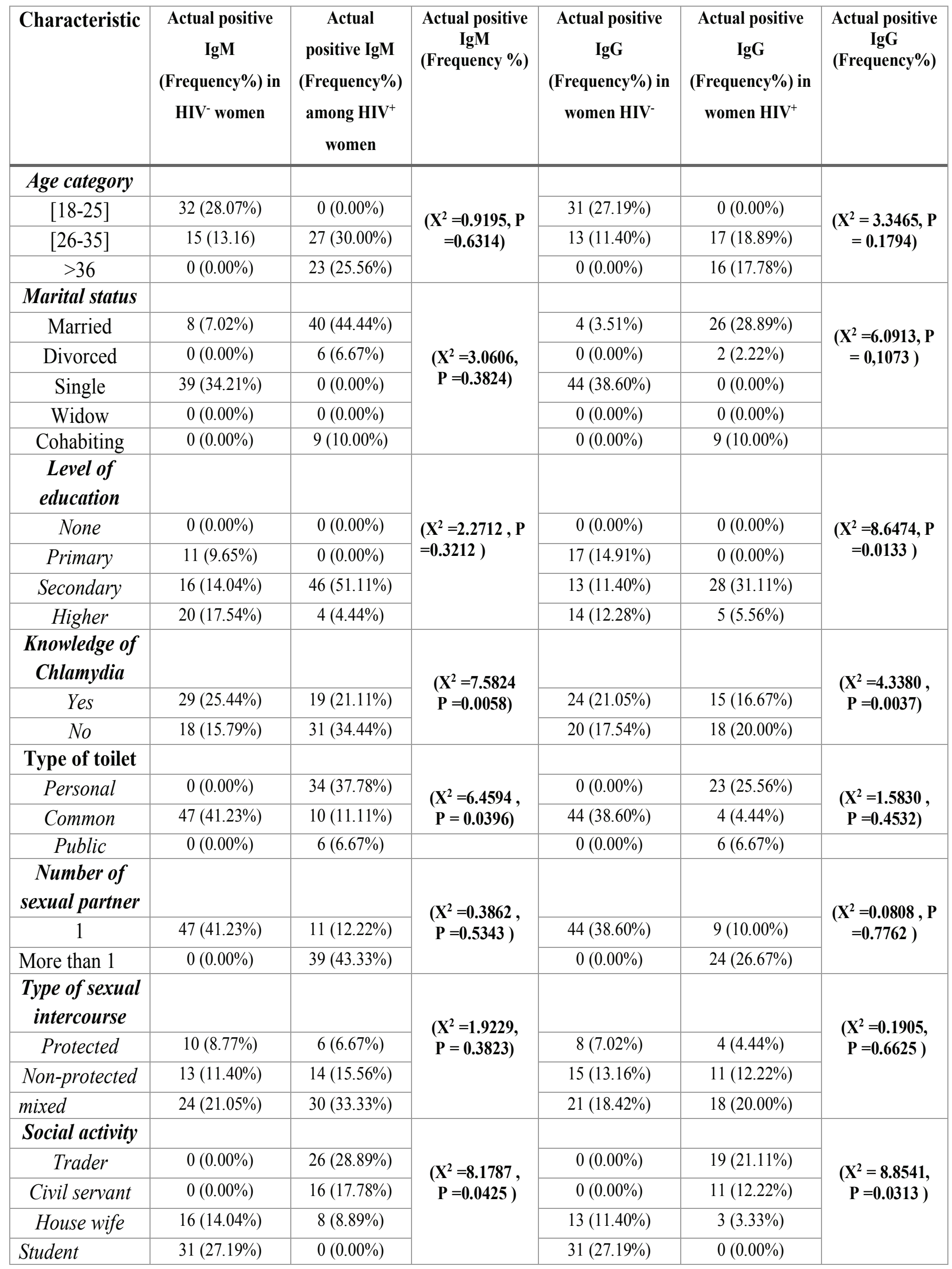


Table 4: Simple logistic regression with suspected variables

\begin{tabular}{|c|c|c|c|c|c|}
\hline \multirow[t]{2}{*}{ Variable } & \multirow{2}{*}{$\begin{array}{c}\text { No of subjects tested } \\
\mathrm{N}(\%)\end{array}$} & \multicolumn{2}{|l|}{ IgM } & \multicolumn{2}{|l|}{ IgG } \\
\hline & & $\begin{array}{l}\text { Odd ratio } \\
(95 \% \mathrm{CI})\end{array}$ & $p$ value & $\begin{array}{l}\text { Odd ratio } \\
(95 \% \mathrm{CI})\end{array}$ & $p$ value \\
\hline $\begin{array}{c}\text { Age category } \\
18-35\end{array}$ & 161 & \multirow[t]{2}{*}{$1.122(0.46-2.71)$} & \multirow[t]{2}{*}{0.7} & \multirow[t]{2}{*}{$0.783(0.33-1.85)$} & \multirow[t]{2}{*}{0.5} \\
\hline$>36$ & 43 & & & & \\
\hline $\begin{array}{c}\text { Marital status } \\
\text { Married }\end{array}$ & 116 & \multirow[t]{2}{*}{$0.448(0.20-1.38)$} & \multirow[t]{2}{*}{0.03} & \multirow[t]{2}{*}{$1.365(0.63-2.95)$} & \multirow[t]{2}{*}{0.4} \\
\hline Unmarried & 88 & & & & \\
\hline $\begin{array}{c}\text { Knowledge of Clhlamydia } \\
\text { Yes }\end{array}$ & 121 & \multirow[t]{2}{*}{$0.295(0.14-0.59)$} & \multirow[t]{2}{*}{0.001} & \multirow[t]{2}{*}{$0.544(0.28-1.04)$} & \multirow[t]{2}{*}{0.06} \\
\hline No & 83 & & & & \\
\hline $\begin{array}{c}\text { Type of toilet } \\
\text { Personal }\end{array}$ & 55 & \multirow[t]{2}{*}{$0.553(0.22-1.38)$} & \multirow[t]{2}{*}{0.2} & \multirow[t]{2}{*}{$0.572(0.23-1.04)$} & \multirow[t]{2}{*}{0.2} \\
\hline Public & 149 & & & & \\
\hline $\begin{array}{c}\text { Type of sexual } \\
\text { intercourse } \\
\text { Protected }\end{array}$ & 42 & \multirow[t]{2}{*}{$1.385(0.66-2.88)$} & \multirow[t]{2}{*}{0.3} & \multirow[t]{2}{*}{$1.654(0.77-3.57)$} & \multirow[t]{2}{*}{0.1} \\
\hline Non-protected & 162 & & & & \\
\hline $\begin{array}{l}\text { HIV status } \\
\text { Negative }\end{array}$ & & \multirow[t]{2}{*}{$1.78(1.01-3.15)$} & \multirow[t]{2}{*}{0.04} & \multirow[t]{2}{*}{$0.92(0.52-1.63)$} & \multirow[t]{2}{*}{0.7} \\
\hline Positive & & & & & \\
\hline
\end{tabular}

Table 5: Multiple logistic regression of selected variables (to be selected by the statistitiant)

\begin{tabular}{|c|c|c|c|c|c|}
\hline \multirow[t]{2}{*}{ Variable } & \multirow{2}{*}{$\begin{array}{c}\text { No of subjects tested } \\
\text { N (\%) }\end{array}$} & \multicolumn{2}{|l|}{$\operatorname{IgM}$} & \multicolumn{2}{|l|}{$\mathrm{IgG}$} \\
\hline & & $\begin{array}{l}\text { Odd ratio } \\
(95 \% \mathrm{CI})\end{array}$ & $\mathrm{p}$ value & $\begin{array}{l}\text { Odd ratio } \\
(95 \% \mathrm{CI})\end{array}$ & $p$ value \\
\hline $\begin{array}{c}\text { Marital status } \\
\text { Married }\end{array}$ & 116 & \multirow[t]{2}{*}{$0.441(0.20-0.96)$} & \multirow[t]{2}{*}{0.03} & \multirow[t]{2}{*}{$1.03(0.52-2.10)$} & \multirow[t]{2}{*}{0.9} \\
\hline Unmarried & 88 & & & & \\
\hline $\begin{array}{c}\text { Knowledge of Clhlamydia } \\
\text { Yes }\end{array}$ & 121 & \multirow[t]{2}{*}{$0.3(0.15-0.60)$} & \multirow[t]{2}{*}{0.001} & \multirow[t]{2}{*}{$0.518(0.27-0.98)$} & \multirow[t]{2}{*}{0.04} \\
\hline No & 83 & & & & \\
\hline $\begin{array}{l}\text { HIV status } \\
\text { Negative }\end{array}$ & & \multirow[t]{2}{*}{$1.48(0.74-2.96)$} & \multirow[t]{2}{*}{0.2} & \multirow[t]{2}{*}{$1.06(0.52-2.16)$} & \multirow[t]{2}{*}{0.8} \\
\hline Positive & & & & & \\
\hline
\end{tabular}

\section{References:}

1. WHO. Global strategy for intervention and control of sexually transmitted infections: 2006-2015.2007; Geneva: World Health Organization.

2. Fenton KA, Lowndes CM. Recent trends in the epidemiology of sexually transmitted infections in the Europe Union. Sex Transm Infect.2004;80:255-63.

3. LaMontagne DS, Patrick LE, Fine DN, Marrazzo JM. Reevaluating selective screening criteria for chlamydial infection among women in the US Pacific Northwest. Sex Transm Dis.2004;31:283-9.

4. Da Ros CT, Schmitt CS. Global epidemiology of sexually transmitted diseases. Asian J Androl.2008;10:110-4.

5. Nordquist C. What is chlamydia? What causes chlamydia? Int J STD AIDS. 2009; 19(7):113-115.

6. Land JA, JeamVB, Morrée SA, and Postma MJ. "Epidemiology of Chlamydia trachomatis infection in women and the costeffectiveness of screening," Human Reproduction Update.2009; 16(2,) 189-204.

7. Adachi K, Klausner JD, Bristow CC, Xu J, Ank B, Morgado MG, Watts DH, Weir F, Persing D, Mofenson LM, Veloso VG, Pilotto JH, Joao E. Nielsen-Saines K. NICHD HPTN 040 Study Team Chlamydia and Gonorrhea in HIV-Infected Pregnant Women and Infant HIV Transmission. Sex Transm 
Dis.2015;42(10):554-65.

8. Morhason-Bello I, Ojengbede O, Oladokun A, Adedokun B, Ajayi A, Adeyanju A, Ogundepo O, Kareem O. The prevalence and outcome of asymptomatic chlamydial infection screening among infertile women attending gynecological clinic in Ibadan, South west Nigeria. Ann Med Health Sci Res.2014); 4(2): 253 7. doi:10.4103/2141-9248.129057.

9. Takuva S, Mugurungi O, Mutsvangwa J, Machiha A, Mupambo AC, Maseko V, Cham F, Mungofa S, Mason P, Lewis DA. Etiology and antimicrobial susceptibility of pathogens responsible for urethral discharge among men in Harare, Zimbabwe. Sex Transm Dis.2014; 41(12):713-7.

10. Rebe K, Lewis D, Myer L, de Swardt G, Struthers H, Kamkuemah M, McIntyre J. A cross sectional analysis of gonococcal and chlamydial infections among menwho-have-sex-with-men in Cape Town, South Africa. PLoSOne.2015;10(9):e0138315. doi:10.1371/journal. pone.0138315.

11. Fleming DT, Wasserheit JN. From epidemiological synergy to Public Health policy and Practice: the contribution of other sexually transmitted disease to sexual transmission of HIV infection. Sex TransmInfect. 1999; $75: 3-17$

12. PaavonenJ. Eggert-Kruse W. Chlamydia trachomatis. Impact on human reproduction. Hum repport Update. 1999;5 : 433-447 13. Wasserheit JN. Epidemiological synergy: Interrelationships between human immunodeficiency virus infection and other sexually transmitted diseases. Sex Transm Dis.1992; 19:61-77. 14. Gray RH, Wawer MJ, Brookmeyer R, et al. Probability of HIV-1 transmission per coital act in monogamous, heterosexual, HIV-1-discordant couples in Rakai, Uganda. Lancet.2001; 357:1149-53, 14.

15. Ghys PD, Fransen K, Diallo MO, et al. The associations between cervicovaginal HIV shedding, sexually transmitted diseases and immunosuppression in female sex workers in Abidjan, Cote d'Ivoire. AIDS.1997; 11:F85-93.

16. Flemming DT, Wasserheit JN. From epidemiological synergy to public health policy and practice: the contribution of other sexually transmitted diseases to sexual transmission of HIV infection. Sex Trans Dis. 1999; 13:3-17.

17. Miller WC, Ford CA, Morris M, Handcock MS, Schmitz JL, Hobbs MM, Cohen MS, Harris KM, Udry JR. Prevalence of chlamydial and gonococcal infections among young adults in the United States. JAMA. 2004;291(18):2229-36.

18. Ryan KA, Zekeng L, Roddy RE, Wei SS. Prevalence and prediction of sexually transmitted disease among sex workers in Cameroon, international journal of STD and AIDS.1998; 1 (13): $1-8$

19. Kaptue L, Zekeng L, Djoumessi S, Monny-Lobe M, Nichols D, and Debuyssher HIV and chlamydia infections among prostitutes in Yaounde, Cameroon. Genetourin. 1991; 67: 143145

20. SanouSobze Martin, Donfack, Jean Hubert, Onohiol James-Francis, Mbongue Germaine, Watcho Pierre, FokamJoseph, Nkamedjie Pete Patrick Martial,DjeunangDonghoGhyslaineBruna, Colizzi Vittorio, Russo Gianluca, MpoameMbidaPrevalence of HIV, HBV and Chlamydia Infections in Cameroonian University Context: Case of the University of Dschang, in the Western Region. International Journal of Health Sciences \& Research, 2015;5(2) 265-273

21. MafokwaneTshepoMalesela and SamieAmidou. Prevalence of chlamydia among HIV positive and HIV negative patients in the Vhembe District as detected by real time PCR from urine samples, BMC Res Notes. 2016;9:102; 2-10

22. PintoValdirMonteiro, TancredMarizaVonoTancredi, da Silva Roberto Jose de Carvalho, KhouryZarifa,Buchallaand Cássia Maria.Prevalence and factors associated with Chlamydia trachomatis infection among women with HIV in São Paulo. Rev Soc Bras Med Trop.2016; 49(3):312-318,

23. Dubbink JH, van der Eem L, Mbambazela N, Struthers H, Ouburg S, McIntyre JA, Morre SA, Peters RPH. Lower prevalence of chlamydia and gonorrhoea among HIV-positive women in rural Mopani District, South Africa. XIX international AIDS conference 2012, Abstract; TUPE141.

24. Plummer FA, Simonsen JN, Cameron OW. Cofactors in male female sexual transmission of human immunodeficiency virus type -1. Journal of infectiousDiseases. 1991;163: 233-239. 25. Joyee AG, Thyagarajan SP, Reddy EV, Venkatetesan C, Ganapathy M. Genital Chlamydia infection in STD patients: its relation to HIV infection. Indian Journal of medicalmicrobiology. 2005;23:37-40.

26. A. Dangana DD, FredrickCC, andEgentiBN. Anti-chlamydia trichomatis igg positivity among HIVpositive women in Abuja, north central Nigeria. Journal of Disease and Global Health.2016;5(4): 186-192

27. Ghys PD, Fransen K, Diallo MO, EthiegneTraore V, Coulibaly IM, Yeboue KM, Kalish ML, Maurice C, Whitaker JP, Greenbarg AE, Laga M. The associations between cervicovaginal HIV shedding sexually transmitted diseases and immuno suppression in female sex workers in Abidjan, Cote d'lvoire. AIDS. 1997;11:f85-f93.

28. Low N, Egger M. What should we do about screening for genital Chlamydia? (Editorial). International Journal of Epidemiology. 2002; 31:891-893.

29. Mamodou S, Laoulkader A, Rabiou S, Aboubacar A, Soumana O, Garba A, Delaporte E, Mboup S. Prevalence of the HIV infection and five other sexually transmitted infection among sex workers in Niamey, Niger. Bull Soc PatholExot. 2006;99:19-22.

30. Kesavaram P, Susethira AR, KrishnanP, Rajasekaran S, Kailapuri A. Shanmugasundaram MU. IgM ELISA: A Better Choice for the Detection of Active Chlamydia trachomatis Infection among HIV Patients. Journal of Clinical and Diagnostic Research. 2012 ; 6(1): 34-37

31. Hani GO, DaghestaniMH, and MohamedMF. Seropositivity of chlamydia trachomatis among Saudi pregnant women in makkah. J Family Community Med.2006;13(2): 61-64

32. Okoror LE, Agbonlahor DE, Esumeh FI, Umolu PI. Prevalence of chlamydia in patients attending gynecological clinics in south eastern Nigeria. Afri Health Sci. 2007;7(1):1824

33. Hurkchand $H$, Makuluma $H$, Molefe $N$, Molapo $M$. Measuring the impact of HIV and STIs in a community in a coal mining town, Mpumalanga, South Africa. J S AFR I MIN METALL. 2005;105:365-8

34. Corsenac P, Noël M, Rouchon B, Hoy D, Roth A. Prevalence and sociodemographic risk factors of chlamydia, gonorrhoea and syphilis: a national multicentre STI survey in New Caledonia, 2012.BMJ Open. 2015;9(5): 1-9.

35. Lorimer K,. Hart JG. Knowledge of Chlamydia trachomatis amongmen and women approached to participate in communitybased screening, Scotland, UK. BMC Public Health. 2010 ; 
10:794

36. Galvin SR, Cohen MS. The role of sexually transmitted diseases in HIV transmission. Nat Rev Microbiol. 2004; 2:3342. PMID: 15035007

37. Boily MC, Baggaley RF,Wang L, Masse B,White RG, Hayes RJ, et al. Heterosexual risk of HIV-1 infection per sexual act: systematic review and meta-analysis of observational studies. Lancet Infect Dis. 2009. 9:118-129.

38. McKinnon LR, Izulla P, NagelkerkeN, Munyao J,Wanjiru T, Shaw SY, et al. Risk factors for HIV acquisition in a prospective Nairobi-based female sex worker cohort. AIDS Behav. 2015; 19(12): 2204-13

39. Chun HM, Carpenter RJ, Macalino GE, Crum-Cianflone
NF. The Role of Sexually Transmitted Infections in HIV-1 Progression: A Comprehensive Review of the Literature. J Sex Transm Dis. 2013;2013:176459.

40. Remis RS, Liu J, Loutfy MR, Tharao W,Rebbapragada A, Huibner S, et al. Prevalenceof Sexually Transmitted Viral and Bacterial Infectionsin HIV-Positive and HIV-Negative Men Who HaveSex with Men in Toronto. PLoS ONE. 2016;11(7):e0158090. doi:10.1371/journal.pone.0158090

41. Kucinskiene V, Sutaite I, Valiukeviciene S, Milassauskiene Z, DomeikaM.Prevalence and risk factors of genital Chlamydia trachomatis infection; Medicina (Kaumas). 2006; 42(11): 885894 